\title{
Toxic effects of Alexandrium spp. on heterotrophic dinoflagellates: an allelochemical defence mechanism independent of PSP-toxin content
}

\author{
Urban Tillmann*, Uwe John
}

Alfred Wegener-Institute for Polar and Marine Research, Am Handelshafen 12, 27570 Bremerhaven, Germany

\begin{abstract}
Sixteen strains of the red tide dinoflagellate Alexandrium spp. were tested for their short-term effects on the heterotrophic dinoflagellates Oblea rotunda and Oxyrrhis marina. Some Alexandrium strains, but not others, caused loss of motility and cell lysis of the heterotrophic dinoflagellates. A live counting procedure using $O$. marina was developed to quantify these toxic effects, which were compared with HPLC estimates of paralytic shellfish poisoning (PSP) toxin content. Within 5 strains, for which PSP toxins could be verified, both non-effective as well as effective strains were present and the same holds true for the other strains without detectable PSP toxins. This clearly indicates that the toxic effects are not due to PSP toxins. The observed effects are caused by extracellular substances, because $O$. marina did not ingest Alexandrium spp. and lytic effects are also found in cell-free culture medium. The immobilisation effect was strongly dependent on the Alexandrium spp. cell concentration. $\mathrm{EC}_{50}$ concentration (Alexandrium spp. cell concentration which caused $50 \%$ immobilisation after $1 \mathrm{~h}$ exposure), as estimated for 5 effective strains, ranged from $2.1 \times 10^{3}$ cells $\mathrm{ml}^{-1}$ down to $0.6 \times 10^{3}$ cells $\mathrm{ml}^{-1}$. A quantitative comparison experiment showed that both heterotrophic dinoflagellate species are immobilised, with the thecate species $(O$. rotunda) being even more affected compared to the athecate O. marina.
\end{abstract}

KEY WORDS: Alexandrium $\cdot$ Heterotrophic dinoflagellates $\cdot$ Allelochemicals $\cdot$ Lytic activity $\cdot$ PSP toxins

\section{INTRODUCTION}

Dinoflagellates of the genus Alexandrium are responsible for the occurrence of paralytic shellfish poisoning (PSP), a neurological affliction that has caused human illness for centuries (Prakash et al. 1971). As a consequence, there have been a large number of investigations spanning morphology, biochemistry, toxicity, genetics, bloom dynamics and evolution, making the genus Alexandrium arguably the best characterised harmful algal species known (Cembella 1998, Scholin 1998). Toxicity research has focused on the phycotoxin saxitoxin and its more than 20 naturally occurring derivates (Shimizu 1996). Their specific significance as compounds of cellular metabo-

*E-mail: utillmann@awi-bremerhaven.de lism, however, is poorly understood. The frequent cooccurrences of HAB blooms and shellfish-borne toxicity or fish kills have fostered the notion that such blooms develop because the bloom species are phycotoxic. In this regard, the idea that PSP toxin production in Alexandrium spp. might be an adaptation for grazer defence has received great attention, as reduced or inhibited grazing is generally believed to be an important factor in harmful bloom dynamics (Fiedler 1982, Smayda 1997). Indeed, Shaw et al. (1997) recently showed that a mixture of pure PSP toxins, dissolved in seawater, behaved as a feeding deterrent without lethal effects to the copepod Tigriopus californicus. Recent results of Teegarden (1999) suggest that cells containing PSP toxins can be discerned by copepod grazers prior to ingestion and thus can be rejected without mortal damage. This is, however, in contrast to earlier observations, which showed that PSP-toxicity of 
food items was apparently not a factor in food selection for the copepod species Acartia tonsa and Eurytemora herdmani (Teegarden \& Cembella 1996). Huntley et al. (1986) found that some dinoflagellate species caused inhibition of grazing in the copepods Calanus pacificus and Paracalanus parvus. Three of the rejected dinoflagellate species produced known neurotoxins. However, other species not known to be toxic also were rejected and some species, which produce PSP toxins, were not rejected as food. Based on that evidence, they hypothesized that substances not associated with PSP toxins were inhibiting grazing. From experiments using filtrates of the rejected algal species they further concluded that potential inhibitory substances were extracellular exudates. Other studies strengthened the view that grazing interaction between Alexandrium spp. and copepods are highly variable and can vary greatly among zooplankton species. PSP-toxic strains of Alexandrium spp. were rejected (Turriff et al. 1995) or ingested at lower rates in response to increasing toxicity (Ives 1985, 1987). Enhanced mortality upon exposure to Alexandrium spp. (Bagoien et al. 1996), reasonable high ingestion rates of toxic Alexandrium spp. with no apparent physiological effects (Teegarden \& Cembella 1996) as well as negative long term effects such as reduction of fecundity or lower hatching success (Dutz 1998, Frangopulos et al. 2000) have been observed.

Although there are many papers on copepod grazing studies, there are only a few dealing with grazing interactions of protozoa and Alexandrium spp. Ciliates (Prakash 1963, Watras et al. 1985) and heterotrophic dinoflagellates (Carreto et al. 1986, Sampayo 1998, Matsuyama et al. 1999) can be found at high concentrations during field blooms of PSP-producing dinoflagellates. Subsequent laboratory growth experiments using protozoan cultures yielded mixed results; the tintinnid Favella ehrenbergii is able to grow on $A$. tamarense at low concentrations (Stoecker et al. 1981), but the growth response of $F$. ehrenbergii on $A$. tamarense is clone-specific (Hansen 1989). At higher Alexandrium spp. concentrations, however, toxic effects became apparent, which, based on indirect evidence, were attributed to PSP toxins (Hansen et al. 1992). Matsuoka et al. (2000) conducted laboratory experiments using the heterotrophic dinoflagellate Polykrikos kofoidii and noted widely varying feeding and growth responses to various strains of Alexandrium spp.: some strains, including both PSP-toxic and non-toxic strains, supported rapid growth, whereas others rapidly caused cell death of the heterotrophic dinoflagellate. In a subsequent paper, ingestion of PSP-toxic Alexandrium spp. cells was thought to be the cause of P. kofoidii cell lysis (Cho \& Matsuoka 2000).

In order to clarify the role of PSP toxins or potentially of other substances in Alexandrium spp./protozoa interactions, the present paper analyses the effects of Alexandrium spp. on heterotrophic dinoflagellates using a wide range of different Alexandrium spp. strains, for which PSP toxins were simultaneously analysed.

\section{MATERIALS AND METHODS}

Alexandrium cultures. Table 1 gives an overview of the different strains of Alexandrium spp. tested in the present study.

All strains were grown non-axenically with IMR 1/2 medium (Eppley et al. 1967), supplemented with selenite (Dahl et al. 1989), or K-medium (Keller et al. 1987) (see Table 1) under controlled conditions at $15^{\circ} \mathrm{C}$ with

Table 1. Overview of Alexandrium species/strains tested

\begin{tabular}{|c|c|c|c|c|}
\hline Alexandrium species & Strain no. & Origin $(\mathrm{yr})$; collector & Culture medium & Doubling time $(\mathrm{h})$ \\
\hline A. affine & CCMP112 & Ria de Vigo, Spain (1985); I. Bravo & $\mathrm{K}$ & 63 \\
\hline A. catenella & BAH255 & Spain; M. Delgado & IMR $1 / 2$ & 40 \\
\hline A. lusitanicum & BAH91 & Laguna de Obidos, Portugal (1996) & $\mathrm{K}$ & 77 \\
\hline A. minutum & AL1T & Mediterranean, Gulf of Trieste; A. Beran & $\mathrm{K}$ & 41 \\
\hline A. minutum & AL3T & Mediterranean, Gulf of Trieste; A. Beran & $\mathrm{K}$ & 32 \\
\hline A. ostenfeldii & BAH136 & New Zealand, Timaru (1992); N. Berkett & $\mathrm{K}$ & 150 \\
\hline A. ostenfeldii & $\mathrm{k}-0324$ & Limfjord, Denmark & $\mathrm{K}$ & 82 \\
\hline A. ostenfeldii & $\mathrm{k}-0287$ & Limfjord, Denmark & IMR $1 / 2$ & 95 \\
\hline A. pseudogonyaulax & $\mathrm{AP} 2 \mathrm{~T}$ & Mediterranean, Gulf of Trieste; A. Beran & $\mathrm{K}$ & 75 \\
\hline A. tamarense & GTPP01 & Perch Pond, Falmouth, MA (1984); D. Kulis & IMR $1 / 2$ & 50 \\
\hline A. tamarense & SZNB01 & Mediterranean, Gulf of Naples (1999); M. Montresor & or $\quad$ IMR $1 / 2$ & 58 \\
\hline A. tamarense & BAH181 & Orkney Island (1997); M. Elbrächter & IMR $1 / 2$ & 40 \\
\hline A. tamarense & CCMP115 & Tamar estuary, UK (1957); I. Adams & IMR $1 / 2$ & 59 \\
\hline A. tamarense & $31 / 9$ & Southern England; W. Higman & IMR $1 / 2$ & 44 \\
\hline A. tamarense & GTLI21 & Mud Creek, Long Island (1981); D. Anderson & IMR $1 / 2$ & 55 \\
\hline A. taylori & AY1T & Mediterranean, Lagoon of Marano; A. Beran & $\mathrm{K}$ & 130 \\
\hline
\end{tabular}


artificial light at $100 \mu \mathrm{E} \mathrm{m}^{-2} \mathrm{~s}^{-1}$ and a light:dark cycle of 16:8 h. Growth of algal cultures was followed by cell counts using the Utermöhl-technique to ensure that cells taken for experiments or for filtration for toxin analysis were in exponential growth phase. The corresponding doubling times of all strains are listed in Table 1.

Cultures of heterotrophic dinoflagellates. The heterotrophic dinoflagellate Oblea rotunda was isolated by capillary isolation from a brackish pond near Büsum (Germany) in 1993. Stock cultures held in multiwell plates or a $100 \mathrm{ml}$ flask were fed with the raphidophyte Fibrocapsa japonica, which recently was shown to sustain rapid growth of $O$. rotunda (Tillmann \& Reckermann 2002). Cultures were transferred about once a week to fresh medium containing late exponential F. japonica cells. Oxyrrhis marina (Göttingen culture collection, Strain B21.89) was grown with Dunaliella sp. as food algae. Stock cultures of both heterotrophic dinoflagellates were maintained at $20^{\circ} \mathrm{C}$ and natural light. Cultures of heterotrophic dinoflagellates used in the experiments were grown to high densities until they became almost deprived of food.

PSP toxin analysis. For toxin analysis, 30 to $50 \mathrm{ml}$ of exponentially growing Alexandrium culture were gently filtered through $0.2 \mu \mathrm{m}$ polycarbonate membrane filters (Nuclepore). The sample preparation protocol by Hummert et al. (1997) was applied for extraction. Briefly, $1 \mathrm{ml}$ of acetic acid $(0.03 \mathrm{~N})$ was added to the algal filter, which was homogenized for 2 min using a Sonopuls HD 70 ultrasonic probe (Bandelin), and centrifuged for $10 \mathrm{~min}(2980 \times g)$. The supernatant was passed through a $0.45 \mu \mathrm{m}, 25 \mathrm{~mm}$ diameter PTFE filter (No. H250.1, Carl Roth) and subsequently injected into the LC equipped with a fluorescence detector. For determination of $\mathrm{N}$-sulfocarbamoyltoxins $150 \mu$ l of the acetic acid extract were mixed with $37 \mu \mathrm{l}$ of $1.0 \mathrm{~N}$ hydrochloric acid and heated for $15 \mathrm{~min}$ at $90^{\circ} \mathrm{C}$. After cooling down to room temperature the mixture was neutralized with $75 \mu \mathrm{l}$ of $1.0 \mathrm{~N}$ sodium acetate. N-sulfocarbamoyltoxins concentrations were calculated by the difference (increase) of the peak areas to those obtained by acetic acid extract. The toxin analyses were performed by automated HPLC applying ion-pair chromatographic separation, post-column oxidation with periodic acid, and fluorescence detection, based on the method of Thielert et al. (1991) with modifications as described detailed in Hummert et al. (1997) and $\mathrm{Yu}$ et al. (1998). LC was performed with an SIL10A intelligent autosampler, an LC-10ATvp intelligent pump, an SCL-10Avp system controller, a 1 ml CRX400 post-column reaction unit (Pickering Laboratories), two LC-9A pumps for delivery of post-column reaction solutions, and an RF-10Axl fluorescence detector (all Shimadzu). Data were analyzed with Class-vp 5.3 soft- ware from Shimadzu. Saxitoxin (STX), neosaxitoxin (NEO) and gonyautoxins (GTXs) as PSP toxin standards were purchased from the National Research Council, Marine Analytical Chemistry Standards Program (NRC-PSP-1B), Halifax, Nova Scotia, Canada. The standard solutions of GTX2 and GTX3 contained dcGTX2 and dcGTX3 as minor components, but the exact content of these toxins was not given. dcSTX was provided by the European Commission (BCR, The Community Bureau of Reference, Brussels), for use as a standard during an intercalibration exercise from 1995 to 1996. All chemicals used were analytical grade.

Effects of Alexandrium spp. Initial experiments were carried out in order to qualitatively monitor the effects of different strains of Alexandrium spp. on Oblea rotunda. O. rotunda mixed with Alexandrium spp. (3000 cells $\mathrm{ml}^{-1}$ final concentration) were inspected under a stereomicroscope after 1 and $24 \mathrm{~h}$ of exposure. This visual inspection, however, was unsatisfactory since most Alexandrium spp. strains and $O$. rotunda are very similar in size and swimming behaviour, and making a clear differentiation between both cell types extremely difficult. In order to quantitatively study the effects of different strains of Alexandrium spp., the following experimental procedure was developed. We used the heterotrophic dinoflagellate Oxyrrhis marina, which can be easily distinguished from Alexandrium spp. by size, cell shape, and swimming pattern, even at low magnification under a dark-field stereomicroscope. Aliquots of $0.5 \mathrm{ml}$ of a dense $O$. marina culture (3000 to 6000 cells ml ${ }^{-1}$ ) were mixed with $1 \mathrm{ml}$ of sample. After a defined exposure time at ambient light and room temperature, the number of moving $O$. marina cells was estimated using a droplet-counting procedure: $100 \mu \mathrm{l}$ of cell suspension was separated into 25 to 30 small droplets in a petri dish and the number of swimming $O$. marina cells was counted under a stereo microscope. The original concentration of $O$. marina initially resulted in a total of 100 to 200 moving cells, which could be counted within 3 to $5 \mathrm{~min}$. Reproducibility of this counting procedure as checked in a preliminary experiment using filtered seawater as sample was satisfactory; repeated subsample counts of the same sample yielded a SD of $5.9 \%(115.3 \pm 6.8 ; \mathrm{n}=10)$ and triplicate subsample counts of 10 different samples one after the other pipetted in different wells yielded a SD of $8.2 \%$ $(115.2 \pm 9.4 ; \mathrm{n}=10)$. In addition to the live counting procedure, subsamples were fixed with lugol's solution and counted with an inverted microscope. After exposure to some of the Alexandrium spp. strains, O. marina lost its motility, thereafter became rounded, and then increased in size due to swelling and finally lysed. In the fixed samples, a cell was only scored if the normal cell shape was still visible. 
Based on this counting procedure the following experiment was carried out: In multidish wells, $1.5 \mathrm{ml}$ of Oxyrrhis marina cells were mixed with $3 \mathrm{ml}$ of Alexandrium tamarense (Strain 31/9), resulting in a final concentration of $3.9 \times 10^{3} \mathrm{~A}$. tamarense $\mathrm{ml}^{-1}$. One-quarter $\mathrm{ml}$ was fixed for cell counts, and $0.1 \mathrm{ml}$ was counted using the droplet method outlined above at time 0,20 , 40, 60, 120 and $180 \mathrm{~min}$. A control experiment was carried out in a similar way using IMR $1 / 2$ medium instead of the A. tamarense culture. The experiment was carried out in triplicate.

Based on the results from these experiments, the following procedure was used in all subsequent experiments: $1 \mathrm{ml}$ of algal sample was mixed to $0.5 \mathrm{ml}$ of Oxyrrhis marina culture. IMR 1/2 medium was used as a control. After $1 \mathrm{~h}$ of exposure at ambient light and room temperature, the number of moving O. marina was counted using the droplet method. Results are always expressed as percentage of moving cells compared to the control. After $3 \mathrm{~h}$ of exposure, $0.25 \mathrm{ml}$ were removed into small settling-chambers (diameter $10 \mathrm{~mm}$ ), fixed with lugol's solution and counted under an inverted microscope. To compare different Alexandrium spp. strains, the effects on $O$. marina were tested using exponentially growing algal cultures when they reached cell concentrations resulting in a final cell density of about $3 \times 10^{3} \mathrm{ml}^{-1}$. The non-toxic dinoflagellate $S c r i p p$ siella trochoidea was used as a control test species.

Dependence of cell concentration. For some strains of Alexandrium, algal cell concentration-dependence of the immobilisation effect on Oxyrrhis marina (droplet counts after $1 \mathrm{~h}$ incubation) was analysed. Therefore, exponentially growing cultures of Alexandrium spp. were tested as described above at several different points of the growth curve representing different cell concentrations (note that algae taken at different stages of the growth curve may differ in the per cell activity potential). Percentages of immobilisation were transformed to probits (Hewlett \& Placklet 1979). EC 50 values, defined as the amount of algae needed to induce $50 \%$ immobilisation after $1 \mathrm{~h}$ of incubation, were calculated using linear regression analysis of probits against log-transformed Alexandrium spp. concentrations.
Test of cell-free filtrate. In some experiments, the effect of culture filtrate of Alexandrium spp. on Oxyrrhis marina was tested. A few $\mathrm{ml}$ of exponentially growing Alexandrium spp. culture (same cell concentration as used for parallel whole cell incubations) were gently filtered using either $10 \mu \mathrm{m}$ gauze or 0.2 $\mu \mathrm{m}$ membrane filters (Sartorius Minisart filters). The filtrate was added to $O$. marina and the samples analysed as described before.

Quantitative comparison between Oxyrrhis marina and Oblea rotunda. One experiment was conducted in order to quantitatively compare the immobilisation effect on O. marina and O. rotunda. A quantitative estimate using $O$. rotunda was possible using Alexandrium tamarense Strain 31/9, because its dark pigmentation and slow swimming speed allowed for a tedious but reliable application of the life counting droplet method. One $\mathrm{ml}$ of a dense $O$. rotunda culture (ca. $500 \mathrm{cells} \mathrm{ml}^{-1}$ ) was mixed with $1 \mathrm{ml}$ of $A$. tamarense 31/9 (final algal concentration in the mixture: 3200 cells ml$^{-1}$ ) or $1 \mathrm{ml}$ of $0.2 \mu \mathrm{m}$ filtrate, respectively. After $1 \mathrm{~h}$ of exposure at ambient light and room temperature, $500 \mu$ l of the mixture was separated into 25 to 30 small droplets in a petri dish and the number of swimming $O$. rotundata was counted under a stereomicroscope. For O. marina, $0.5 \mathrm{ml}$ (ca. 5000 cells $\mathrm{ml}^{-1}$ ) were mixed with $0.75 \mathrm{ml}$ of $A$. tamarense culture (Strain 31/9) and $0.25 \mathrm{ml} \mathrm{IMR} \mathrm{1/2}$ medium (resulting as above in a likewise final algal concentration of $3200 \mathrm{ml}^{-1}$ ) or $0.75 \mathrm{ml}$ of filtrate and $0.25 \mathrm{ml}$ IMR $1 / 2$ medium. The experiment then proceeded as described above. For both heterotrophic dinoflagellates a control experiment was carried out in a similar way using IMR 1/2 medium instead of the $A$. tamarense culture. All treatments were done in triplicate.

\section{RESULTS}

\section{Toxin analysis}

PSP toxins could be detected in 5 of the 16 Alexandrium species/strains (Table 2). All these strains produced only small amounts of PSP toxins, with total

Table 2. Paralytic shellfish poisoning (PSP)-toxin content and toxin profile of Alexandrium species/strains. For all other species/ strains tested (see Table 1), no PSP toxins could be detected

\begin{tabular}{|c|c|c|c|c|c|c|c|c|c|c|}
\hline \multirow{2}{*}{$\begin{array}{l}\text { Alexandrium spp. } \\
\text { strain }\end{array}$} & \multirow{2}{*}{$\begin{array}{l}\text { PSP-toxin content } \\
\quad\left(\text { fmol cell }^{-1}\right)\end{array}$} & \multicolumn{9}{|c|}{ PSP-toxin profile (mol \%) } \\
\hline & & GTX1 & GTX2 & GTX3 & GTX4 & $\mathrm{Neo}$ & STX & $\mathrm{B}_{1}$ & $\mathrm{~B}_{2}$ & $\mathrm{C}_{1+2}$ \\
\hline A. minutum (AL3T) & 3.0 & 56.6 & 5.3 & 3.3 & 34.7 & 0 & 0 & 0 & 0 & 0 \\
\hline A. lusitanicum (BAH91) & 16.6 & 51.5 & 4.1 & 3.7 & 41.4 & 0 & 0 & 0 & 0 & 0 \\
\hline A. catenella (BAH255) & 9.9 & 0 & 0 & 0 & 0 & 0 & 0.6 & 20.2 & 26.1 & 53.1 \\
\hline A. tamarense (BAH181) & 42.3 & 11.9 & 6.9 & 7.6 & 7.2 & 12.8 & 11.6 & 3.1 & 3.5 & 35.5 \\
\hline A. tamarense (GTPP01) & 33.4 & 14.2 & 0.9 & 1.2 & 16.0 & 3.6 & 0.3 & 7.0 & 1.5 & 55.4 \\
\hline
\end{tabular}


PSP-toxin content ranging from $3.0 \mathrm{fmol} \mathrm{cell}^{-1}$ (A. minutum AL3T) to $42.3 \mathrm{fmol} \mathrm{cell}^{-1}$ (A. tamarense BAH181). The toxin profile was quite similar for A. minutum AL3T and A. lusitanicum BAH91 with a predominance of GTX1 and GTX4. For A. catenella BAH255 the sulfoxycarbamyl toxins $\mathrm{B}_{1,2}$ and $\mathrm{C}_{1+2}$ were predominant, but small amounts of STX also were found. The PSPtoxin profiles of the 2 strains of A. tamarense (BAH181, GTPP01) were quite similar, but showed a high percentage of Neo and STX for the clone isolated near the Orkney Islands (BAH181) (Table 2).

\section{Effects of Alexandrium spp. on heterotrophic dinoflagellates}

Preliminary qualitative observations revealed rapid negative effects on the thecate heterotrophic dinoflagellate Oblea rotunda when exposed to different Alexandrium spp. strains. As observed under a stereomicroscope, cells tended to disappear from the water column and concentrate at the bottom, either immobilized or only slow moving. Rapidity and strength of effects appeared to vary among different Alexandrium spp. strains. With some algal strains, $O$. rotunda seemed to be less affected and grazer attacks and pallium feeding events were observed. However, most Alexandrium spp. strains and $O$. rotunda are very similar in size and swimming behaviour, making a clear differentiation between the species extremely difficult. Although rapid immobilisation effects were intuitively apparent for some Alexandrium spp. strains, the approach using $O$. rotunda was not practical for detailed quantification of short-term effects. We therefore used the heterotrophic dinoflagellate Oxyrrhis marina as a test organism. It can be easily distinguished from Alexandrium spp. by size, cell shape, and swimming pattern, even at low magnification under a dark-field stereomicroscope.

Microscopic observations showed that certain Alexandrium spp. strains caused the heterotrophic dinoflagellate Oxyrrhis marina to lose motility and then become rounded. Subsequently, cells swelled and finally lysed. The time course of these effects was followed after addition of $O$. marina to A. tamarense (Strain 31/9, final concentration of $3.9 \times 10^{3} \mathrm{ml}^{-1}$ ) (Fig. 1). The effect of immobilisation, as estimated by the life-counting droplet method, was very rapid. The first sample could not be processed before 3 min after mixing, and by this time motility was significantly less than that of controls mixed with IMR $1 / 2$ medium ( $t$ test, $\mathrm{p}<0.05$ ). Results of the following experiments therefore are always expressed as percentage of moving cells compared to controls. After $20 \mathrm{~min}$ of expo-
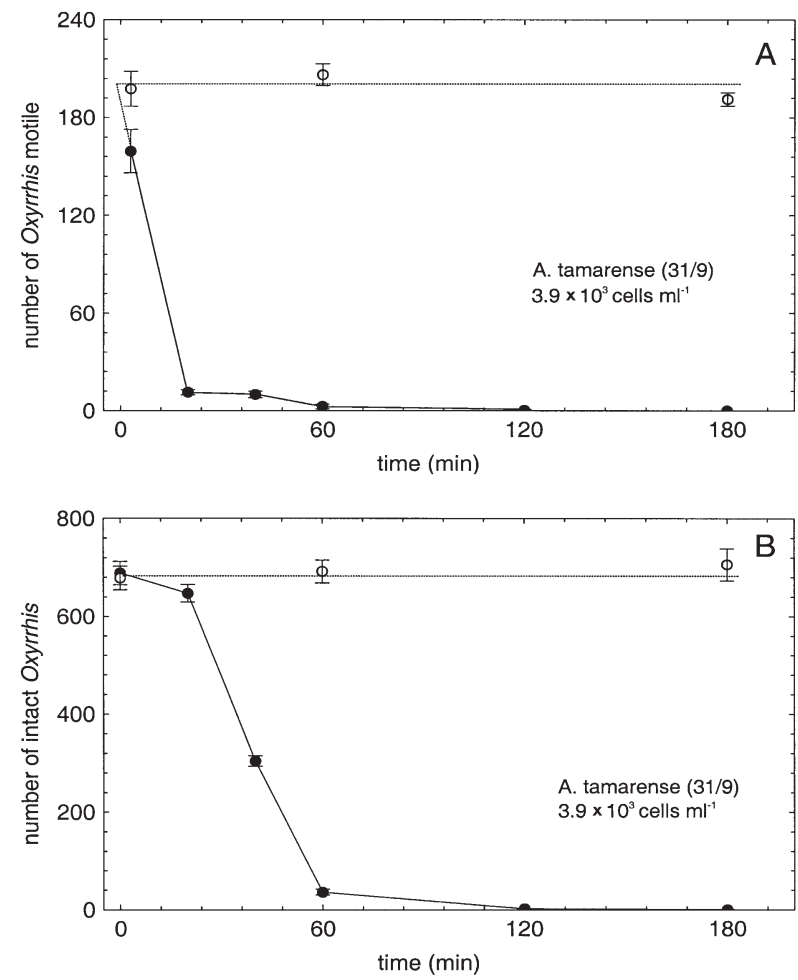

Fig. 1. Number of (A) motile Oxyrrhis marina (live counts) or (B) intact $O$. marina (fixed cell counts) as a function of exposure time to $(\bullet)$ Alexandrium tamarense (31/9, added to

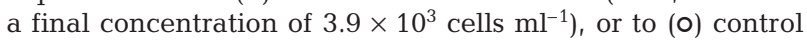
(IMR 1/2 medium added). Data points refer to treatment means $\pm 1 \mathrm{SD}(\mathrm{n}=3)$

sure the number of moving $O$. marina was drastically reduced and an exposure time of 60 min resulted in a nearly $100 \%$ immobilisation. Cell lysis, as derived from counts of visible intact cells after fixation, was slower than immobilisation (Fig. 1B) with a nearly complete lysis after 2 to $3 \mathrm{~h}$ of exposure. Effects of different Alexandrium spp. strains thus were subsequently studied using live counts (droplet method) after $1 \mathrm{~h}$ exposure and fixed cell counts after $3 \mathrm{~h}$ of exposure.

\section{Comparison of different Alexandrium spp. strains}

Effects of different Alexandrium spp. strains were analysed at comparable final cell concentrations of about $3 \times 10^{3} \mathrm{ml}^{-1}$. The exact numbers are listed in Table 3. The percentage of Oxyrrhis which became immobilised after $1 \mathrm{~h}$ exposure varied considerably among the different Alexandrium spp. strains tested (Fig. 2A). The response varied from unaffected (e.g. A. minutum AL3T) to a nearly $100 \%$ immobilisation in some strains (e.g. A. tamarense SZNB01). Cell 
Table 3. Final cell concentrations of Alexandrium species/ strains tested for their effects on Oxyrrhis marina (see Fig. 2). conc.: concentration

\begin{tabular}{|lcc|}
\hline $\begin{array}{l}\text { Alexandrium } \\
\text { species }\end{array}$ & Strain no. & $\begin{array}{c}\text { Final conc. } \\
\left(10^{3} \mathrm{ml}^{-1}\right)\end{array}$ \\
\hline A. affine & CCMP112 & 2.6 \\
A. catenella & BAH255 & 2.6 \\
A. lusitanicum & BAH91 & 4.0 \\
A. minutum & AL1T & 5.0 \\
A. minutum & AL3T & 3.2 \\
A. ostenfeldii & BAH136 & 2.9 \\
A. ostenfeldii & k-0324 & 2.7 \\
A. ostenfeldii & k-0287 & 3.0 \\
A. pseudogonyaulax & AP2T & 2.4 \\
A. tamarense & GTPP01 & 3.0 \\
A. tamarense & SZNB01 & 3.8 \\
A. tamarense & BAH181 & 3.4 \\
A. tamarense & CCMP115 & 3.0 \\
A. tamarense & 31/9 & 2.8 \\
A. tamarense & GTL121 & 4.0 \\
A. taylori & AY1T & 3.2 \\
& & \\
\hline
\end{tabular}
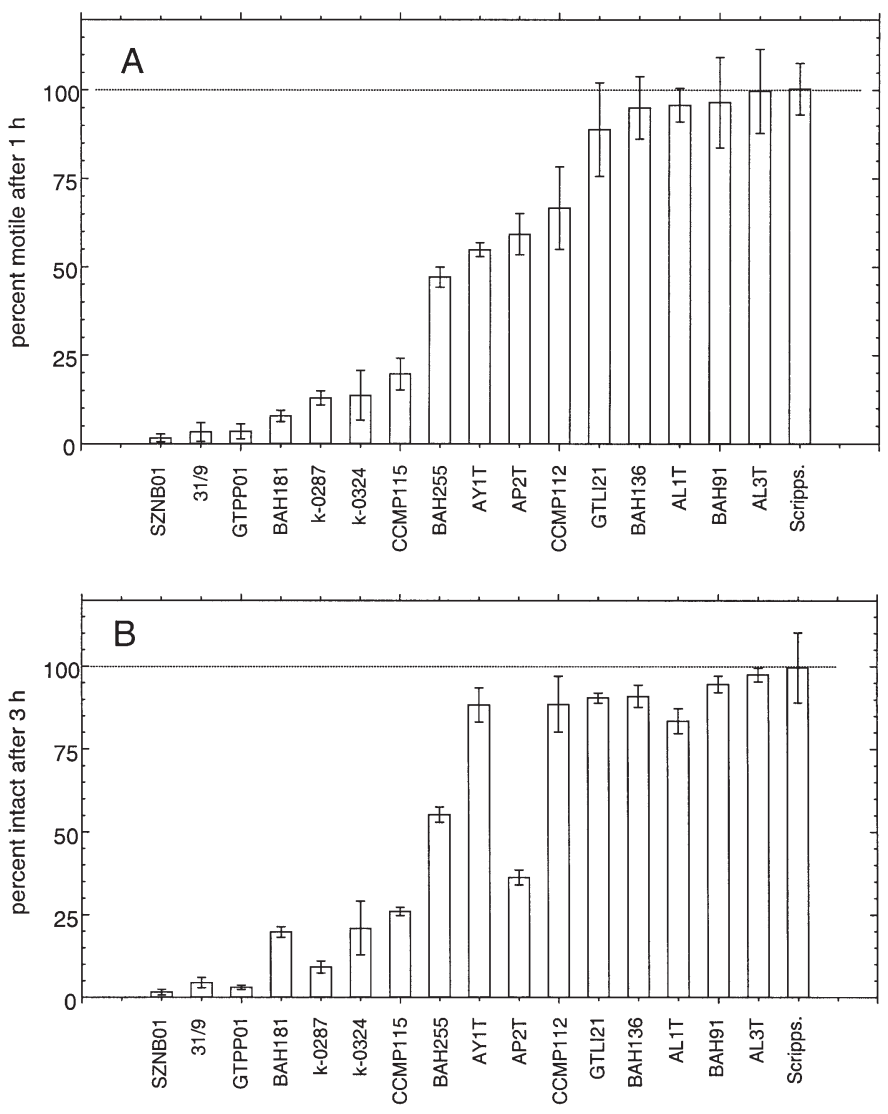

Fig. 2. Percentage of (A) motile Oxyrrhis marina after $1 \mathrm{~h}$ exposure (live counts) or (B) intact $O$. marina after $3 \mathrm{~h}$ exposure (fixed cell counts) to different species/strains of Alexandrium. Scripps.: Scrippsiella trochidea $\left(3.2 \times 10^{3}\right.$ cells ml$\left.^{-1}\right)$ used as a control test species. Final algal cell concentrations are listed in Table 3. Results expressed as triplicate mean $\pm 1 \mathrm{SD}$ counts of fixed samples after $3 \mathrm{~h}$ exposure showed comparable results (Fig. 2B). No negative effects could be observed for the non-toxic control species Scrippsiella trochoidea. Differences in the strength of effects could not be related to estimates of PSP toxin content (Fig. 3). The most effective strains included both strains without PSP toxins (e.g. SZNB01) and with PSP toxins (e.g. Strain BAH181). On the other hand, strains with (e.g. AL3T) and without PSP toxins (e.g. GTL129) had no effect at the cell concentration tested.

\section{Dependence of cell concentration}

The immobilisation effect was strongly dependent on the Alexandrium spp. cell concentration for all 5 tested lytic strains (Fig. 4). Data shown in Fig. 4 are pooled from several experiments using different culture runs. Although all cultures were exponentially growing, there is some scatter in the immobilisation effect, which might be due to small differences in algal physiological conditions or in toxin sensibility of Oxyrrhis marina utilised in the different experiments. However, the data clearly show that significant negative short-term effects began to occur at cell concentrations of about 0.2 to $1 \times 10^{3} \mathrm{ml}^{-1}$, depending on the strain. EC $_{50}$ values, defined as the amount of algae needed to induce $50 \%$ immobilisation after $1 \mathrm{~h}$ of incubation, of the 5 tested strains were $2.1 \times 10^{3} \mathrm{ml}^{-1}(A$. catenella BAH255), $1.6 \times 10^{3} \mathrm{ml}^{-1}$ (A. tamarense 31/9), $1.5 \times 10^{3} \mathrm{ml}^{-1}$ (A. tamarense BAH181), $1.0 \times 10^{3} \mathrm{ml}^{-1}(A$. tamarense SZNB01) and $0.6 \times 10^{3} \mathrm{ml}^{-1}$ (A. tamarense GTPP01).

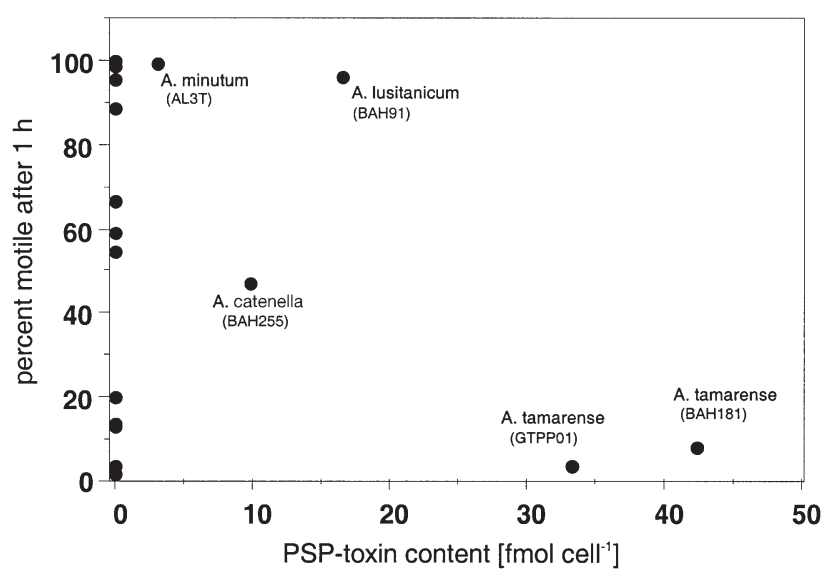

Fig. 3. Relationship between the percentage of motile Oxyrrhis marina after $1 \mathrm{~h}$ of exposure (data from Fig. 2) and PSP-toxin content (fmol cell-1) of the respective Alexandrium species/strain (data from Table 2) 

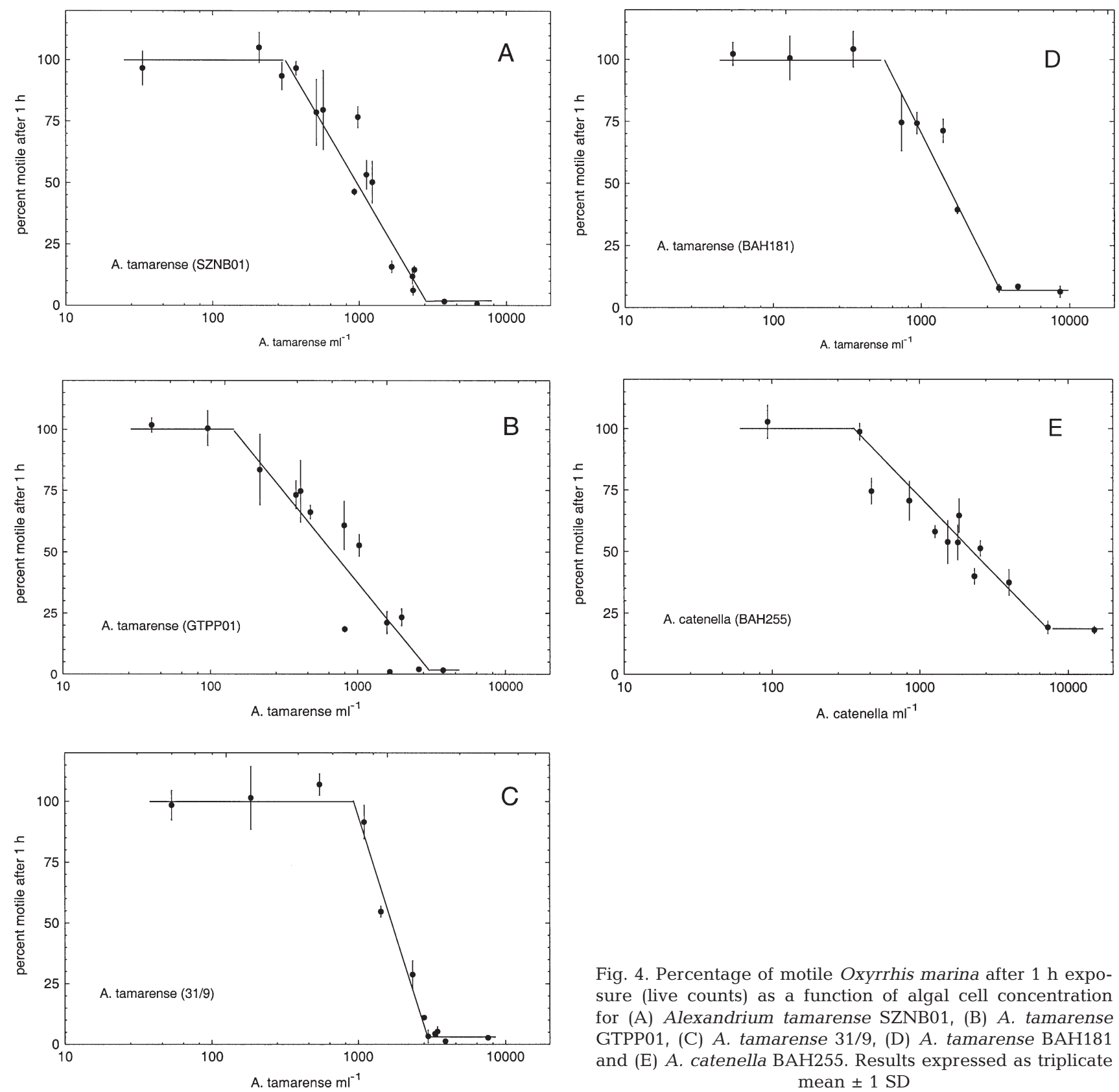

Fig. 4. Percentage of motile Oxyrrhis marina after $1 \mathrm{~h}$ exposure (live counts) as a function of algal cell concentration for (A) Alexandrium tamarense SZNB01, (B) A. tamarense GTPP01, (C) A. tamarense 31/9, (D) A. tamarense BAH181 and (E) A. catenella BAH255. Results expressed as triplicate mean $\pm 1 \mathrm{SD}$

\section{Effect of culture filtrate}

A negative effect on Oxyrrhis marina also was obvious when testing Alexandrium spp. cell free culture filtrate (Fig. 5). The immobilisation effect of cell free filtrate, however, was lower compared to the effect of algal suspensions (same cell concentration as used for the filtrate). There was no difference between the short-term immobilisation effect of filtrate through either gauze $(10 \mu \mathrm{m})$ or a $0.2 \mu \mathrm{m}$ membrane.

\section{Quantitative comparison between Oxyrrhis marina and Oblea rotunda}

In one experiment, the immobilisation effect of Alexandrium tamarense (Strain 31/9) filtrate $(<0.2 \mu \mathrm{m})$ and cells was estimated for both heterotrophic dinoflagellates, Oxyrrhis marina and Oblea rotunda (Fig. 6). Both species are immobilised with the thecate species $O$. rotunda being even more affected compared to the athecate $O$. marina. Here again, negative effects of the cellfree filtrate were less pronounced for both target species. 


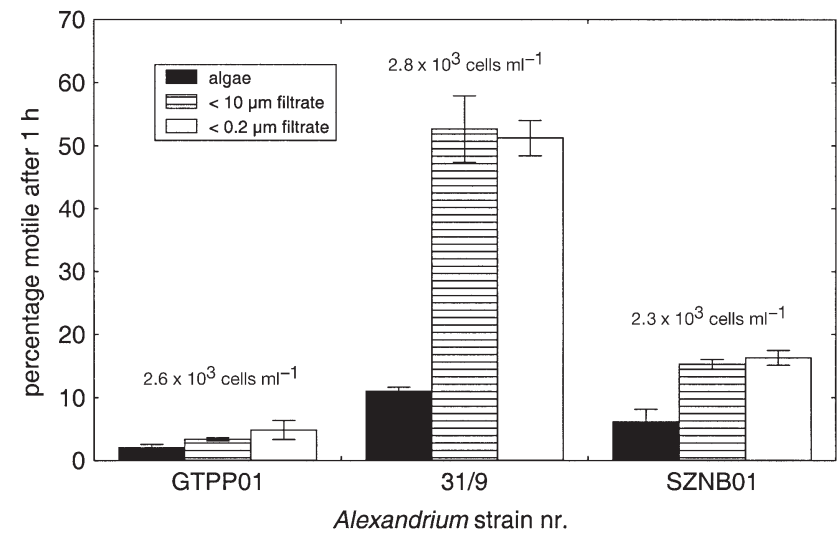

Fig. 5. Percentage of Oxyrrhis marina motile after $1 \mathrm{~h}$ exposure to whole cells, $<10 \mu \mathrm{m}$ filtrate or $<0.2 \mu \mathrm{m}$ filtrate of 3 strains of Alexandrium tamarense (GTPP01, 31/9, SZNB01). Numbers above bars indicate final algal concentraion. Results expressed as triplicate mean $\pm 1 \mathrm{SD}$

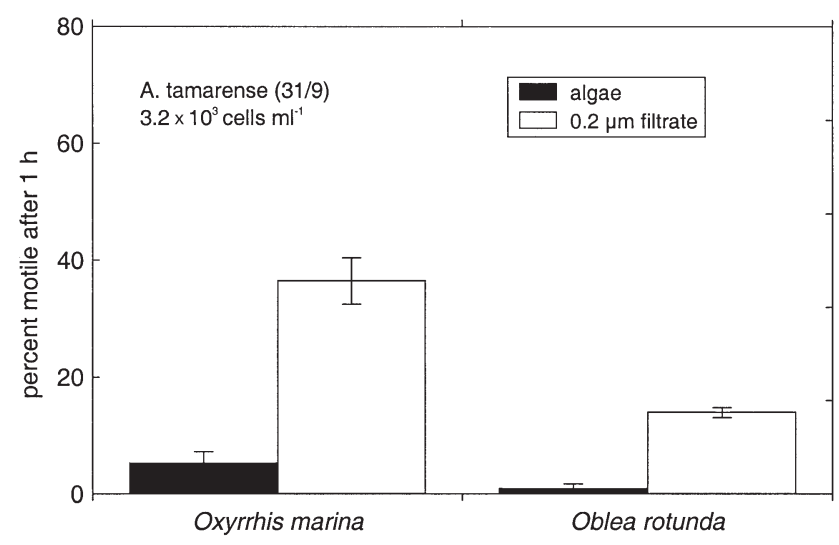

Fig. 6. Effects of A. tamarense (31/9) whole cells and $0.2 \mu \mathrm{m}$ filtrate on Oxyrrhis marina and Oblea rotunda motility after $1 \mathrm{~h}$ of exposure. Results expressed as triplicate mean $\pm 1 \mathrm{SD}$

\section{DISCUSSION}

The results clearly show immobilising/lytic effects of several species/strains of the genus Alexandrium, which could not be explained by PSP-toxin content. The observed toxic effects are caused by extracellular toxins, because (a) Oxyrrhis marina did not ingest Alexandrium spp. and (b) lytic effects also are found in cell-free culture medium. Using non-axenic algal cultures it is important to consider the potential role of bacteria for the observed effects, since it is well known that bacteria may be either directly or indirectly associated with algal toxin production (Doucette et al. 1998). The immobilisation effect of whole algal culture (including bacteria) was higher compared to the effect of culture filtrate, indicating a continual release of toxic substances. However, there was no difference between the effect of filtrate gained either by gauze (10 $\mu \mathrm{m}$, free bacteria should be unalteredly present) or membrane-filters $(0.2 \mu \mathrm{m}$, should remove most bacteria), making involvement of extracellular toxins produced by free bacteria unlikely.

The noxious exudates released by Alexandrium spp. may generally be classified as allelochemicals. Allelochemical secondary metabolites are mainly distinguished from phycotoxins (like PSP toxins), in that phycotoxins can be vectored through the food web, accompanied by broad-based trophodynamic effects, whereas allelochemicals are usually directly targeted. The presented evidence of allelochemical activity of Alexandrium not related to PSP toxins validates a couple of related indications, which can be found widespread in the literature: Ogata \& Kodama (1986) described ichthyotoxic and haemolytic effects in the culture medium of Protogonyaulax (= Alexandrium) catenella and P. tamarense. As they did not find any PSP toxins in the medium, they concluded that the observed effect was caused by factor(s) other than PSP toxins. Haemolytic effects of Alexandrium spp. cell extract were confirmed later (Simonsen et al. 1995, Eschbach et al. 2001). Based on a comparison with the low haemolytic activity of purified STX and GTX1-5 standards, Simonsen et al. (1995) suggested that components other than PSP toxins are likely to be responsible for the haemolytic effects of A. tamarense. Likewise, Lush \& Hallegraeff (1996) attributed toxic effects of whole cells and cell-free culture medium, of A. minutum to Artemia salina, to a fast acting toxin distinct from PSP. Similar toxicity of exudates of A. minutum has been reported upon exposure to the copepod Euterpina acutifrons (Bagoien et al. 1996).

In addition, there are a few papers reporting negative effects of Alexandrium spp. filtrate on other algal species. Blanco \& Campos (1988) showed that culture filtrate of a PSP-toxin-containing A. lusitanicum adversely affected several flagellates (in fact most of the cells were killed), whereas growth of the algal species was not affected by filtrate of a non-PSP-toxin-producing A. tamarense. Based on that comparison, Blanco \& Campos (1988) tentatively ascribed the toxic effect of culture filtrate to PSP toxins. More recently, Arzul et al. (1999) investigated the allelopathic properties in 3 Alexandrium species. They found that the filtrate of all 3 species repressed growth of certain algal species. Allelopathic activity of exponentially growing Alexandrium spp. was positively related to both haemolytic activity and published values of PSP toxicity, probably reflecting correlated metabolic activity. The observed increase in allelopathy at the senescent growth phase led Arzul et al. (1999) to the suggestion, that substances other than STX are present. 
In contrast to the large body of literature with copepods, there are only a few reports dealing with impacts of Alexandrium spp. on heterotrophic protists. A. tamarense has been described as deleterious to the marine heliozoa Heterophrys marina (Tobiesen 1991). Hansen (1989) and Hansen et al. (1992) described effects of Alexandrium spp. on the tintinnid ciliate Favella ehrenbergii. Hansen (1989) studied the behaviour and growth of $F$. ehrenbergii fed with 6 clones of $A$. tamarense producing different levels of PSP toxin. He clearly showed that algae are ingested by the ciliate, but the latter is only affected by exudates in the medium. The exudates induce ciliary reversal resulting in continuous backward swimming, swelling of the ciliate and subsequent cell lysis. Based on indirect evidence, Hansen (1989) suggested that the toxic effect of Alexandrium spp. on ciliates is caused by PSP toxins. However, the same immobilisation effects on F. ehrenbergii were caused by $A$. ostenfeldii, which contained only very small amounts of PSP toxins (Hansen et al. 1992). Four out of 7 Alexandrium tested species/strains sustained growth of the heterotrophic dinoflagellate Polykrikos kofoidii, whereas the protozoan grazer was rapidly killed by 3 strains (Matsuoka et al. 2000). Although Matsuoka et al. (2000) did not measure toxin content, they designated these 3 strains (A. fundyense, A. lusitanicum, A. monilatum) to be toxic (presumably based on literature data). A. monilatum is not known to produce PSP toxins but it synthesizes an unknown ichtyotoxin (Aldrich et al. 1967). Moreover, Matsuoka et al. (2000) reported that both toxic and non-toxic strains (based again on literature data) of $A$. tamarense sustained moderate to rapid growth of $P$. kofoidii, suggesting that, in accordance with the present findings, factors other than PSP toxins are responsible for killing this heterotrophic dinoflagellate. Cho \& Matsuoka (2000) described cell lysis of $P$. kofoidii feeding on a PSP-toxic A. tamarense strain. According to their descriptions and microphotographs, cell lysis occurs after the ingestion of an A. tamarense cell, which was rapidly followed by egestion. In line with the present findings, Cho \& Matsuoko (2000) observed a fast and nearly complete lysis of $P$. kofoidii within $1 \mathrm{~h}$ exposure to an A. tamarense concentration of $2000 \mathrm{ml}^{-1}$. However, in view of the present results, it seems unlikely that cell lysis of $P$. kofoidii is causatively linked to ingestion.

Quantitative findings in the present study were mainly based on Oxyrrhis marina, a species rather atypical for the marine plankton. However, detection of negative effects on $O$. marina, a marine protozoa, are likely of greater ecological significance compared to the rather unspecific impact on blood cells, as obtained with standard haemolytic tests. Both heterotrophic dinoflagellate species are immobilised, with the thecate species Oblea rotunda being even more affected compared to the athecate $O$. marina. Additional qualitative observations of the short term effects of Alexandrium spp. on the thecate species Oblea rotunda as well as the similarity of cell lysis observed for Polykrikos kofoidii (Cho \& Matsuoka 2000), suggest that other heterotrophic dinoflagellates are probably affected in the same way. Moreover, it may be attractive to ascribe the whole range of observed negative effects of Alexandrium spp. culture medium on blood cells (haemolytic effects), heterotrophic protozoa (immobilisation/cell lysis; Hansen 1989, this study), algae (growth repression/cell lysis; Blanco \& Campos 1988, Arzul et al. 1999) or copepods (grazing inhibition; Huntley et al. 1986) to one single chemical compound. However, Arzul et al. (1999) concluded that the allelopathic activity of Alexandrium spp. is caused by a complex of chemicals, rather than by a specific substance. Almost nothing is known about the chemical composition of such compounds. The experiments with culture filtrate at least indicate that these substances are water-soluble but labile in culture media. Immobilisation activity of whole cells was higher compared to culture filtrate (Figs. $5 \& 6$; see also Hansen 1989) and thus probably due to a continual release of substances by the cells. Comparable lytic or allelopathic effects caused by other algal species are mainly thought to be due to glycolipids and polyunsaturated fatty acids. For example, digalactosylglycerol and octapentaenoic acid isolated by Yasumoto et al. (1990) have been shown to be both haemolytic (Yasumoto et al. 1990) and inhibitory to diatom growth (Gentien \& Arzul 1990, Arzul et al. 1995).

The strength of immobilisation/lytic activity at comparable cell concentrations varied considerably among the different Alexandrium species/strains tested. It has been repeatedly established that cultured strains of toxic algae, such as Alexandrium spp. or Chrysochromulina spp., are typically less toxic than those collected from natural populations (White 1986, Cembella et al. 1988, Edvardsen 1993). They also may vary considerably with respect to cellular toxin content (Anderson 1990, Chang et al. 1997, Edvardsen \& Paasche 1998, Parkhill \& Cembella 1999) and toxin profile (Cembella 1998). Within the genus Alexandrium, lytic activity of the tested strains seems not to be related to certain species. Even though allelochemical effects are insignificant for all tested species of the A. minutum/lusitanicum species complex (Strains AL3T, AL1T, BAH91, see Fig. 2), there is evidence that other strains of the same species complex exude lytic compounds (A. minutum: Lush \& Hallegraeff 1996; A. lusitanicum: Blanco \& Campos 1988). For the tested strains which appeared to be less effective, it can not be excluded that lytic effect may be apparent at higher cell concentrations and/or longer exposure times. 
Our results confirm that a large variety of combinations of PSP and lytic compounds may occur among different Alexandrium spp. strains. Ecophysiological consequences of allelochemicals, however, may mimic phycotoxin effects, making it difficult to trace back observed effects to single compounds, unless many strains covering a whole range of combinations of phycotoxins and allelochemical compounds are tested. Evidence that toxic effects, grazing inhibition, and prey selection in crustacean grazers exposed to Alexandrium spp. are caused by substances not associated with PSP (Huntley et al. 1986, Bagoien et al. 1996, Lush \& Hallegraeff 1996, Teegarden \& Cembella 1996) has already been noted above. In addition, there are a couple of reports indicating that copepods are affected by lytic exudates of other toxic algae (Gill \& Harris 1987, Nielsen et al. 1990, Uye \& Takamatsu 1990). Species/ strain specific production of allelochemicals in addition to or instead of PSP toxins thus might partly explain some of the contradictory results on copepod grazing of Alexandrium spp. (reviewed in Turner \& Tester 1997).

The power to immobilise or kill potential predators surely is of adaptive significance for a HAB species to form dense and long lasting blooms. To assess the potential impact in situ, however, a comparison between cell concentrations used in the present laboratory experiments and those occurring during Alexandrium spp. blooms, is needed. Alexandrium spp. are often considered to be 'background' bloom species, in that they often are outnumbered by co-occurring phytoplankton (Anderson 1998). Indeed, a compilation presented by Wyatt \& Jenkinson (1997) indicated relatively low numbers of 20 to $400 \mathrm{cell} \mathrm{m}^{-1}$ as peak cell concentrations reached by Alexandrium spp. during blooms in different regions. However, high-biomass, monospecific blooms that discolour the water do occur, including those of $A$. minutum in south Australia (Hallegraeff et al. 1988), or dense blooms (>1000 ml-1) of A. tamarense (= Gonyaulax excavata) in the Argentine Sea (Carreto et al. 1986). In the Mediterranean, dense blooms of Alexandrium spp. with maximum concentrations up to 60000 cells $\mathrm{ml}^{-1}$ are repeatedly observed (Vila et al. 2001, and references therein). For the short-term immobilisation effect as observed in the present study, $\mathrm{EC}_{50}$ cell concentrations (defined as the cell concentration which caused $50 \%$ of immobilisation) were in the range from $1600 \mathrm{ml}^{-1}$ down to 600 $\mathrm{ml}^{-1}$ for the 5 tested strains. This is in the same range of reported Alexandrium spp. cell concentrations required to induce $50 \%$ backwards swimming of the ciliate Favella ehrenbergii within 10 min (Hansen 1989). Comparing these numbers with bloom concentrations cited above, we suggest that once a bloom reaches sufficiently high Alexandrium spp. concentrations, allelochemicals indeed can prevent the population from any substantial protozoan grazing. A 'blow out' of at least the protozoan grazers may explain why some Alexandrium spp. blooms can persist for months (Mortensen 1985, Carreto et al. 1986). Sublethal, longterm negative effects of lower Alexandrium spp. cell concentrations on protozoans are poorly known. According to Hansen (1989) F. ehrenbergii is killed by a PSP-toxic $A$. tamarense strain at high cell concentrations but showed ingestion and rapid growth when fed with low concentrations $\left(<1000 \mathrm{ml}^{-1}\right)$ of the same strain. This suggests that grazing by protozooplankton might be of significance in controlling the development of a bloom if the concentration of algae is low and the concentration of predators is sufficiently high. However, extensive investigations on potential longterm effects of sublethal concentrations of allelochemicals on protozoan grazers still have to be carried out.

In addition to eliminating competitors and/or grazers, allelochemical activity may be coupled with mixotrophic nutrition, as was suggested for the haptophytes Prymnesium patelliferum (Tillmann 1998) and Chrysochromulina (Estep \& MacIntyre 1989). Alexandrium spp. are generally considered to be mainly autotrophic, but food vacuoles containing ciliates or phytoplankton cells have been observed in A. ostenfeldii (Jacobson \& Anderson 1996). Moreover, it recently was shown that some species of Alexandrium have the capacity to take up high molecular weight organic molecules (Carlsson et al. 1998, Legrand \& Carlsson 1998), to utilize organic $\mathrm{N}$-substances for growth and toxin production (Ogata et al. 1996) and to remove dissolved free amino acids down to concentrations similar to those found in natural waters (John \& Flynn 1999). It thus might be speculated that Alexandrium spp. probably benefits from enhanced concentrations of dissolved organic matter in consequence of its lytic activity.

There can be no doubt that PSP toxins, through their neurotoxic effects on sea animals and humans, represent the most threatening property of Alexandrium spp. However, for the ecological success of Alexandrium spp., that is, to produce dense and long-lasting blooms, it is suggested that the allelochemical potential of Alexandrium spp., through its direct destructive effects on competing algae or unicellular grazers, is of much greater significance.

Acknowledgements. The authors gratefully acknowledge Elke Jaim (Friedrich-Schiller University Jena) for the PSPtoxin measurement. We greatly appreciate the effort of all people that have isolated and made available the strains listed in Table 1. Thanks are due to Allan Cembella for constructive criticism and suggestions, and to Steve Pueppke for correcting the English. This work was partly supported by the German BMBF (TEPS project 03F0161) and by the European Commission (Research Directorate General-Environment 
Programme-Marine Ecosystems) through the BIOHAB project 'Biological control of Harmful Algal Blooms in European coastal waters: role of eutrophication' (contract EVK3-CT9900015). The BIOHAB project is part of the EC EUROHAB cluster.

\section{LITERATURE CITED}

Aldrich DV, Ray SM, Wilson WB (1967) Gonyaulax monilata: population growth and development of toxicity in cultures. J Protozool 14:636-639

Anderson DM (1990) Toxin variability in Alexandrium species. In: Granéli E, Sundström B, Edler L, Anderson DM (eds) Toxic marine phytoplankton. Elsevier Science Publisher, New York, p 41-51

Anderson DM (1998) Physiology and bloom dynamics of toxic Alexandrium species, with emphasis on life cycle transitions. In: Anderson DM, Cembella AD, Hallegraeff GM (eds) Physiological ecology of harmful algae blooms. Springer-Verlag, Berlin, p 29-48

Arzul G, Gentien P, Bodennec G, Toularastel F, Youenou A, Crassus MP (1995) Comparison of toxic effects in Gymnodinium cf. nagasakiense polyansaturated fatty acids. In: Lassus P, Arzul G, Gentien P, Marcaillou C (eds) Harmful marine algal blooms. Lavoisier, Intercept, p 395-400

Arzul G, Seguel M, Guzman L, Erard-LeDenn E (1999) Comparison of allelopathic properties in three toxic Alexandrium species. J Exp Mar Biol Ecol 232:285-295

Bagoien E, Miranda A, Reguera B, Franco JM (1996) Effects of two paralytic shellfish toxin producing dinoflagellates on the pelagic hapacticoid copepod Euterpina acutifrons. Mar Biol 126:361-369

Blanco J, Campos MJ (1988) The effect of water conditioned by a PSP-producing dinoflagellate on the growth of four algal species used as food for invertebrates. Aquaculture 68:289-298

Carlsson P, Edling H, Béchemin C (1998) Interactions between a marine dinoflagellate (Alexandrium catenella) and a bacterial community utilizing riverine humic substances. Aquat Microb Ecol 16:65-80

Carreto JI, Benavides HR, Negri RM, Glorioso PD (1986) Toxic red-tide in the Argentine Sea. Phytoplankton distribution and survival of the toxic dinoflagellate Gonyaulax excavata in a frontal area. J Plankton Res 8:15-28

Cembella AD (1998) Ecophysiology and metabolism of paralytic shellfish toxins in marine microalgae. In: Anderson DM, Cembella AD, Hallegraeff GM (eds) Physiological ecology of harmful algal blooms. Springer-Verlag, Berlin, p 381-403

Cembella AD, Therriault JC, Béland P (1988) Toxicity of cultured isolates and natural populations of Protogonyaulax tamarensis from the St. Lawrence Estuary. J Shellfish Res 7:611-621

Chang FH, Anderson DM, Kulis DM, Till DG (1997) Toxin production of Alexandrium minutum (Dinophyceae) from the Bay of Plenty, New Zealand. Toxicon 35:393-409

Cho HJ, Matsuoka K (2000) Cell lysis of a phagotrophic dinoflagellate, Polykrikos kofoidii feeding on Alexandrium tamarense. Plankton Biol Ecol 47:134-136

Dahl E, Lindahl O, Paasche E, Throndsen J (1989) The Chrysochromulina polylepis bloom in Scandinavian waters during spring 1988. In: Cosper EM, Bricelj VM, Carpenter EJ (eds) Novel phytoplankton blooms: causes and impacts of recurrent brown tides and other unusual blooms. Springer-Verlag, Berlin, p 383-405

Doucette GJ, Kodama M, Franca S, Gallacher S (1998) Bacte- rial interaction with harmful algal bloom species: bloom ecology, toxigenesis, and cytology. In: Anderson DM, Cembella AD, Hallegraeff GM (eds) Physiological ecology of harmful algal blooms. Springer-Verlag, Berlin, p 619-647

Dutz J (1998) Repression of fecundity in the neritic copepod Acartia clausi exposed to the toxic dinoflagellate Alexandrium lusitanicum: relationship between feeding and egg production. Mar Ecol Prog Ser 175:97-107

Edvardsen B (1993) Toxicity of Chrysochromulina species (Prymnesiophyceae) to the brine shrimp, Artemia salina. In: Smayda TJ, Shimizu Y (eds) Toxic phytoplankton bloom in the sea. Elsevier Science, Amsterdam, p 681-686

Edvardsen B, Paasche E (1998) Bloom dynamics and physiology of Prymnesium and Chrysochromulina. In: Anderson DM, Cembella AD, Hallegraeff GM (eds) Physiological ecology of harmful algae blooms. Springer-Verlag, Berlin, p 193-208

Eppley RW, Holmes RW, Strickland JDH (1967) Sinking rates of marine phytoplankton measured with a fluorometer. J Exp Mar Biol Ecol 1:191-208

Eschbach E, Scharsack J, John U, Medlin LK (2001) Improved erythrocyte lysis assay in microtitre plates for sensitive detection and efficient measurement of haemolytic compounds from ichthyotoxic algae. J Appl Toxicol 21:513-519

Estep KW, MacIntyre F (1989) Taxonomy, life cycle, distribution and dasmotrophy of Chrysochromulina: a theory accounting for scales, haptonema, muciferous bodies and toxicity. Mar Ecol Prog Ser 57:11-21

Fiedler PC (1982) Zooplankton avoidance and reduced grazing responses to Gymnodinium splendens (Dinophyceae). Limnol Oceanogr 27:961-965

Frangopulos M, Guisande C, Maneiro I, Riveiro I, Franco J (2000) Short-term and long-term effects of the toxic dinoflagellate Alexandrium minutum on the copepod Acartia clausi. Mar Ecol Prog Ser 203:161-169

Gentien P, Arzul G (1990) Exotoxin production by Gyrodinium cf. aureolum (Dinophyceae). J Mar Biol Ass UK 70:571-581

Gill CW, Harris RP (1987) Behavioural responses of the Copepods Calanus helgolandicus and Temora longicornis to dinoflagellate diets. J Mar Biol Ass UK 67:785-801

Hallegraeff GM, Steffensen DA, Wetherbee R (1988) Three estuarine Australian dinoflagellates that can produce paralytic shellfish toxins. J Plankton Res 10:533-541

Hansen PJ (1989) The red tide dinoflagellate Alexandrium tamarense: effects on behaviour and growth of a tintinnid ciliate. Mar Ecol Prog Ser 53:105-116

Hansen PJ, Cembella AD, Moestrup O (1992) The marine dinoflagellate Alexandrium ostenfeldii: paralytic shellfish toxin concentration, composition, and toxicity to a tintinnid ciliate. J Phycol 28:597-603

Hewlett PS, Placklet RL (eds) (1979) The probit and similar transformation. In: An introduction to the interpretation of quantal response in biology. Edward Arnold, London, p 12-17

Hummert C, Ritscher M, Reinhardt K, Luckas B (1997) Analysis of the characteristic PSP profiles of Pyrodinium bahamense and several strains of Alexandrium by HPLC based ion-pair chromatographic separation, post-column oxidation, and fluorescence detection. Chromatographia 45:312-316

Huntley M, Sykes P, Rohan S, Marin V (1986) Chemicallymediated rejection of dinoflagellate prey by the copepod Calanus pacificus and Paracalanus parvus: mechanism, occurence and significance. Mar Ecol Prog Ser 28:105-120 Ives JD (1985) The relationship between Gonyaulax tamaren- 
sis cell toxin levels and copepod ingestion rate. In: Anderson DM, White AW, Baden DG (eds) Toxic dinoflagellates. Elsevier, New York, p 413-418

Ives JD (1987) Possible mechanisms underlying copepod grazing responses to levels of toxicity in red tide dinoflagellates. J Exp Mar Biol Ecol 112:131-145

Jacobson DM, Anderson DM (1996) Widespread phagocytosis of ciliates and other protists by mixotrophic and heterotrophic thecate dinoflagellates. J Phycol 32:279-285

John EH, Flynn KJ (1999) Amino acid uptake by the toxic dinoflagellate Alexandrium fundyense. Mar Biol 133:11-19

Keller MD, Selvin RC, Claus W, Guillard RRL (1987) Media for the culture of oceanic ultraphytoplankton. J Phycol 23: $633-638$

Legrand C, Carlsson P (1998) Uptake of high molecular weight dextran by the dinoflagellate Alexandrium catenella. Aquat Microb Ecol 16:81-86

Lush GJ, Hallegraeff GM (1996) High toxicity of the red tide dinoflagellate Alexandrium minutum to the brine shrimp Artemia salina. In: Yasumoto T, Oshima Y, Fukuyo Y (eds) Harmful and toxic algal blooms. Intergovernal Oceanographic Commision of UNESCO, Paris, p 389-392

Matsuoka K, Cho HJ, Jacobson DM (2000) Observation of the feeding behaviour and growth rates of the heterotrophic dinoflagellate Polykrikos kofoidii (Polykrikaceae, Dinophyceae). Phycologia 39:82-86

Matsuyama Y, Miyamoto M, Kotani Y (1999) Grazing impact of the heterotrophic dinoflagellate Polykrikos kofoidii on a bloom of Gymnodinium catenatum. Aquat Microb Ecol 17: 91-98

Mortensen AM (1985) Massive fish mortalities in the Faroe Islands caused by a Gonyaulax excavata red tide. In: Anderson DM, White AW, Baden DG (eds) Toxic dinoflagellates. Elsevier, New York, p 165-170

Nielsen TG, Kiorboe T, Bjornsen PK (1990) Effects of a Chrysochromulina polylepis subsurface bloom on the planktonic community. Mar Ecol Prog Ser 62:21-35

Ogata T, Kodama M (1986) Ichthyotoxicity found in culture media of Protogonyaulax spp. Mar Biol 92:31-34

Ogata T, Koike K, Nomura S, Kodama M (1996) Utilization of organic substances for growth and toxin production by Alexandrium tamrense. In: Yasumoto $\mathrm{T}$, Oshima Y, Fukuyo Y (eds) Harmful and toxic algal blooms. Intergovernal Oceanographic Commision of UNESCO, Paris, p 343-346

Parkhill JP, Cembella AD (1999) Effects of salinity, light and inorganic nitrogen on growth and toxigenity of the marine dinoflagellate Alexandrium tamarense from northeastern Canada. J Plankton Res 21:939-955

Prakash A (1963) Source of paralytic shellfish toxin in the Bay of Fundy. J Fish Res Board Can 20:983-996

Prakash A, Medcof JC, Tennant AD (1971) Paralytic shellfish poisoning in eastern Canada. Bull Fish Res Board Can 168: $1-87$

Sampayo MA (1998) Polykrikos kofoidii Chatton predation on Gymnodinium catenatum Graham and its effects. In: Reguera B, Blanco J, Fernandez ML, Wyatt T (eds) Harmfull algae. Xunta de Galicia and Intergovernmental Oceanographic Commision of UNESCO, Grafisant, Santiago de Compostella, p 182-183

Scholin CA (1998) Morphological, genetic, and biogeographic relatioships of the toxic dinoflagellates Alexandrium tamarense, A. catenella, and A. fundyense. In: Anderson DM, Cembella AD, Hallegraeff GM (eds) Physiological ecology of harmful algal blooms. Springer-Verlag, Berlin, p $13-27$

Editorial responsibility: Otto Kinne (Editor), Oldendorf/Luhe, Germany
Shaw BA, Andersen RJ, Harrison PJ (1997) Feeding deterrent and toxicity effects of apo-fucoxanthinoids and phycotoxins on a marine copepod (Tigriopus californicus). Mar Biol 128:273-280

Shimizu Y (1996) Microalgal metabolites: a new perspective. Ann Rev Microbiol 50:431-465

Simonsen S, Moller BL, Larsen J, Ravn H (1995) Haemolytic activity of Alexandrium tamarense cells. In: Lassus $\mathrm{P}$, Arzul G, Gentien P, Marcaillou C (eds) Harmful marine algal blooms. Lavoisier, Intercept, p 513-517

Smayda TJ (1997) Harmful algal blooms: their ecophysiology and general relevance to phytoplankton blooms in the sea. Limnol Oceanogr 42:1137-1153

Stoecker D, Guillard RRL, Kavee RM (1981) Selective predation by Favella ehrenbergii (Tintinnida) on and among Dinoflagellates. Biol Bull 160:136-145

Teegarden GJ (1999) Copepod grazing selection and particle discrimination on the basis of PSP toxin content. Mar Ecol Prog Ser 181:163-176

Teegarden GJ, Cembella AD (1996) Grazing of toxic dinoflagellates, Alexandrium spp., by adult copepods of coastal Maine: Implications for the fate of paralytic shellfish toxins in marine food webs. J Exp Mar Biol Ecol 196:145-176

Thielert G, Kaiser I, Luckas B (1991) HPLC determination of PSP toxins. In: Fremy JM (ed) Proceedings of symposium on marine biotoxins. Editions CNEVA, Maisons-Alfort, p 121-125

Tillmann U (1998) Phagotrophy of a plastidic haptophyte, Prymnesium patelliferum. Aquat Microb Ecol 14:155-160

Tillmann U, Reckermann M (2002) Dinoflagellate grazing on the raphidophyte Fibrocapsa japonica. Aquat Microb Ecol 26:247-257

Tobiesen A (1991) Growth rates of Heterophrys marina (Heliozoa) on Chrysochromulina polylepis (Prymnesiophyceae). Ophelia 33:205-212

Turner JT, Tester PA (1997) Toxic marine phytoplankton, zooplankton grazers, and pelagic food webs. Limnol Oceanogr 42:1203-1214

Turriff N, Runge JA, Cembella AD (1995) Toxin accumulation and feeding behaviour of the planktonic copepod Calanus finmarchicus exposed to the red-tide dinoflagellate Alexandrium excavatum. Mar Biol 123:55-64

Uye S, Takamatsu K (1990) Feeding interactions between planktonic copepods and red tide flagellates from Japanese coastal waters. Mar Ecol Prog Ser 59:97-107

Vila M, Camp J, Garcés E, Masó M, Delgado M (2001) High resolution spatio-temporal detection of potentially harmful dinoflagellates in confined waters of the NW Mediterranean. J Plankton Res 23:497-514

Watras CJ, Carcon VC, Olson RJ, Chisholm SW, Anderson DM (1985) The effect of zooplankton grazing on estuarine blooms of the toxic dinoflagellate Gonyaulax tamarensis. J Plankton Res 7:891-908

White AW (1986) High toxin content in the dinoflagellate Gonyaulax excavata in nature. Toxicon 24:605-610

Wyatt T, Jenkinson IR (1997) Notes on Alexandrium population dynamics. J Plankton Res 19:551-575

Yasumoto T, Underdahl B, Aune T, Hormazabal V, Skulberg OM (1990) Screening for hemolytic activity and ichtyotoxic components of Chrysochromulina polylepis and Gyrodinium aureolum from Norwegian coastal waters. In: Granéli E, Sundström B, Edler L, Anderson DM (eds) Toxic Marine Phytoplankton. Elsevier, New York, p 436-440

Yu RC, Hummert C, Luckas B, Qian PY, Yhou MJ (1998) Modified HPLC method for analysis of PSP toxins in algae and shellfish from China. Chromatographia 48:671-675 